\title{
STUDI PENGARUH DOSIS DAN LAMA PENGGUNAAN TERAPI AMINOGLIKOSIDA TERHADAP FUNGSI GINJAL
}

\author{
Cahyani Purnasari ${ }^{1}$, Marianti A.Manggau ${ }^{1}$ dan Hasyim Kasim ${ }^{2}$ \\ ${ }^{1}$ Fakultas Farmasi, Universitas Hasanuddin, Makassar \\ ${ }^{2}$ Fakultas Kedokteran, Universitas Hasanuddin, Makassar
}

Kata Kunci :

Aminoglikosida,

Streptomisin,

Gentamisin, Kanamisin,

Kadar Kreatinin, Kadar

Ureum, Fungsi Ginjal

\section{ABSTRAK}

Penelitian ini bertujuan untuk menganalisa pengaruh penggunaan aminoglikosida, yaitu streptomisin, gentamisin, dan kanamisin, terhadap fungsi ginjal pasien rawat inap di RSUP Dr. Wahidin Sudirohusodo Makassar dengan melihat parameter fungsi ginjal yaitu kadar kreatinin dan ureum serum pasien. Selain itu penelitian ini juga menganalisa pengaruh dari obat-obatan lain yang bisa mempengaruhi fungsi ginjal.Metode untuk penelitian ini adalah penelitian observasional non eksperimen dengan rancangan deskriptif-analitik. Pengambilan sampel dilakukan secara retrospektif, dan didapatkan 32 orang sampel yang memenuhi kriteria inklusi. Berdasarkan uji statistik One Way ANOVA kadar kreatinin dan ureum dari ketiga kelompok obat tersebut tidak menunjukkan perbedaan yang signifikan nilai (Ur, $\mathrm{p}=0.133$ > 0,$05 ; \mathrm{Cr}, \mathrm{p}=0.246>0,05$ ). Dalam penelitian ini terlihat bahwa pada dosis penggunaan sekali sehari pada streptomisin dan kanamisin tidak terjadi peningkatan kadar kreatinin pasien, sedangkan pada kelompok pasien gentamisin yang diterapi dengan dosis terbagi (tiap 12 jam) terjadi peningkatan kadar kreatinin. Untuk lama penggunaan terapi, pada streptomisin hanya kelompok streptomisin kategori D (penggunaan terapi $>31$ hari) dan kelompok terapi gentamisin yang menunjukkan peningkatan kreatinin. Hal ini tampaknya diakibatkan oleh sifat nefrotoksik dari aminoglikosida meningkat seiring dengan lama terapi dan penggunaan dosis terbagi. Selain itu gentamisin juga merupakan jenis aminoglikosida yang lebih toksik dibandingkan dengan streptomisin dan kanamisin karena memiliki sifat kationik yang lebih tinggi.

\section{PENDAHULUAN}

Antimikroba merupakan salah satu jenis obat yang paling sering digunakan. Salah satu masalah yang menjadi hambatan terbesar dalam kesuksesan penggunaan antimikroba adalah berkembangnya mikroba-mikroba resisten. Sejak awal era antibiotik, penggunaan antibiotik pada pasien dan hewan menyebabkan peningkatan kemunculan patogen resisten. Kini mikroba Gram-negatif dengan mekanisme resistensi yang baru semakin sering dilaporkan. Resistensi antibiotik mengakibatkan dampak negati, seperti meningkatkan penggunaan antibiotik yang besifat spektrum-luas, kurang efektif, atau antibiotika yang bersifat toksik (1). Salah satu jenis antibiotik yang bersifat toksik adalah antibiotik jenis aminoglikosida. Aminoglikosida merupakan salah satu jenis antibiotik tertua yang digunakan untuk menangani berbagai infeksi serius yang diakibatkan oleh bakteri gram negatif dan beberapa bakteri jenis gram-positif. Aminoglikosida adalah antibakteri yang bersifat bakterisidal. Beberapa contoh obat-obatan yang masuk ke dalam golongan aminoglikosida antara lain streptomisin, neomisin, kanamisin, amikasin, gentamisin, tobramisin, sisomisin, dan netilmisin. Antibiotika golongan aminoglikosida umumnya digunakan dalam kombinasi bersama antibiotika beta-laktam untuk menangani infeksi serius yang diakibatkan bakteri Gram-negatif, dikombinasikan dengan vancomycin atau antibiotika beta-laktam untuk endokarditis gram-positif, dan untuk terapi tuberkulosis $(1,2)$.

Obat-obatan aminoglikosida menjadi pilihan karena memiliki efek bakterisidal yang cepat, stabil secara kimia, sinergis dengan antibiotika golongan beta-laktam, insiden resistensi yang rendah, dan biaya yang murah. Meskipun demikian aminoglikosida memiliki efek samping yang sangat terkenal, yaitu nefrotoksik dan ototoksik. Efek nefrotoksik dari aminoglikosida mencapai $10-25 \%$ dari total penggunaan terapi walaupun telah dilakukan pemantauan yang teliti. Efek nefrotoksik tersebut berasal dari kemampuannya merusak tubular ginjal (3). Efek nefrotoksik dari aminoglikosida merupakan efek samping yang paling penting dan merugikan dari antibiotik aminoglikosida. Efek ini merupakan salah satu penyebab mengapa pada akhir tahun 1970-an terjadi penurunan penggunaan aminoglikosida dan peningkatan penggunaan antibiotik-antibiotik baru berspektrum luas seperti fluorokuinolon, karbapenem, cefalosporin generasi ke tiga dan empat, dan kombinasi beta laktam/inhibitor beta-laktamase. Walaupun terdapat banyak penelitian yang menunjukkan efek nefrotoksik dari aminoglikosida, belum ada penelitian yang menunjukkan perbedaan efek nefrotoksik antara streptomisin, gentamisin, dan kanamisin (2).

Secara umum, insiden dan tingkat keparahan toksisitas obat secara proporsional berkaitan dengan konsentrasi obat dan lama penggunaan obat tersebut. Kejadian overdosis obat merupakan contoh yang jelas dari toksisitas yang dipengaruhi oleh dosis. Untuk golongan aminoglikosida, kelompok obat ini memiliki sifat concentration dependent killing, yang berarti konsentrasi obat yang lebih tinggi mampu membunuh jumlah bakteri yang lebih banyak dan lebih cepat, dan sifat postantibiotic effect, yang berarti kelompok obat ini memiliki efek antibakteri yang bertahan lama setelah konsentrasi obat berkurang di bawah konsentrasi yang bisa diukur. Karena sifat-sifat tersebut, jumlah total aminoglikosida lebih efektif 
jika diberikan dalam satu dosis besar dibandingkan jika diberikan dalam beberapa dosis kecil. Selain itu efek toksik juga bersifat terikat dengan lama penggunaan dan konsentrasi obat (time-dependent dan concentrationdependent). Berbagai penelitian menunjukkan bahwa dosis tunggal aminoglikosida menunjukkan hasil yang efektif dengan efek toksik yang lebih kecil jika dibandingkan dengan dosis terbagi. Penelitian ini akan melibatkan pemantauan efek streptomisin, gentamisin, dan kanamisin terhadap fungsi ginjal pasien yang dilihat dari parameter berupa kadar kreatinin serum dan urea darah pasien, memperhatikan jenis regimen yang digunakan di RSU Wahidin Sudirohusodo (dosis terbagi atau dosis tunggal per hari) serta apakah terjadi perbedaan onset gejala nefrotoksik pada penggunaan ketiga antibiotik tersebut berdasarkan parameter tradisional fungsi ginjal $(2,3)$.

\section{METODE PENELITIAN}

\section{Rancangan Penelitian}

Jenis penelitian ini adalah penelitian observasional non eksperimen dengan rancangan deskriptif analitik serta metode pengambilan data secara retrospektif.

\section{Populasi dan Sampel Penelitian}

Populasi adalah pasien penyakit infeksi yang diterapi dengan antibiotik jenis aminoglikosida di RSUP Dr. Wahidin Sudirohusodo Makassar. Sampel adalah pasien yang diterapi dengan antibiotika aminoglikosida selama lebih dari dua hari dan berusia $>16$ tahun dalam periode bulan Januari 2017-November tahun 2018.

\section{Pengambilan dan Pengolahan Data Penelitian}

Data hasil pengukuran parameter fungsi ginjal berupa data ureum dan kreatinin serum pasien penderita penyakit infeksi yang dirawat di RSUP Dr. Wahidin Sudirohusodo. Data profil pengobatan dan data klinis pasien dikumpulkan untuk keperluan analisis data yang diperoleh dari data rekam medik dan hasil pemeriksaan laboratorium berupa data ureum dan serum kreatinin. Analisis statistik dilakukan untuk melihat signifikansi perubahan yang terjadi terhadap parameter fungsi ginjal berupa data ureum dan serum kreatinin terhadap kelompok terapi yang diteliti yaitu kelompok terapi streptomisin, gentamisin dan kanamisin.

\section{HASIL DAN PEMBAHASAN}

Subjek penelitian terdiri dari subjek laki-laki sebanyak 21 orang $(65,62 \%)$ dan perempuan sebanyak 11 orang (34,38\%). Distribusi penggunaan antibiotika aminoglikosida adalah 18 orang $(56,25 \%)$ mengunakan streptomisin; 5 orang $(15,63 \%)$ menggunakan gentamisin; 7 orang $(21.88 \%)$ menggunakan kanamisin, dan 2 orang $(6,3 \%)$ menggunakan kombinasi dua aminoglikosida, yaitu kombinasi amikasingentamisin dan kombinasi streptomisin-gentamisin. Hasil uji statistik One Way ANOVA menunjukkan bahwa diperoleh kadar ureum nilai $\mathrm{p}=0.133>0,05$ dan nilai $\mathrm{p}=0.246>0,05$ untuk kadar kreatinin yang menunjukkan bahwa perbandingan pemeriksaan sampel dari pasien yang menggunakan ketiga obat golongan aminoglikosida ini (streptomisin, gentamisin, dan kanamisin) tidak memberikan hasil yang berbeda secara signifikan untuk kadar ureum dan kreatinin.

Pada kelompok streptomisin tampak peningkatan kadar kreatinin pada dosis $500 \mathrm{mg} / 24 \mathrm{jam}$, tetapi peningkatan kreatinin tersebut tidak signifikan (dari $0,61 \mathrm{mg} / \mathrm{dL}$ menjadi $0,62 \mathrm{mg} / \mathrm{dL}$ ), dan terjadi penurunan kadar kreatinin dan urea pada kelompok dosis $750 \mathrm{mg} / 24 \mathrm{jam}$ dan $1 \mathrm{~g} / 24$ jam. Sedangkan pada kelompok gentamisin terjadi peningkatan kadar kreatinin dan ureum pada semua kelompok dosis dengan peningkatan tertinggi pada kelompok dosis $40 \mathrm{mg} / 12$ jam. Hal ini juga tampaknya diakibatkan oleh sifat nefrotoksik aminoglikosida meningkat jika digunakan dalam dosis terbagi, karena tiga dosis yang digunakan dalam kelompok gentamisin ini semuanya merupakan dosis terbagi (masingmasing 40mg/12 jam, $60 \mathrm{mg} / 12$ jam dan $70 \mathrm{mg} / \mathrm{dl})(4,5)$. Pada kelompok kanamisin terjadi peningkatan kadar kreatinin pada pemeriksaan kedua untuk kelompok dosis $750 \mathrm{mg} / 24$ jam, dan terjadi penurunan kadar kreatinin pada pemeriksaan kedua untuk kelompok dosis $500 \mathrm{mg} / 24$ jam dan $1 \mathrm{~g} / 24$ jam. Sedangkan kadar ureum untuk kanamisin menunjukkan hasil sebaliknya, terjadi penurunan kadar ureum di pemeriksaan kedua untuk kelompok dosis $750 \mathrm{mg} / 24 \mathrm{jam}$ dan peningkatan kadar ureum untuk kelompok dosis 500mg/24 jam dan 1g/24 jam.

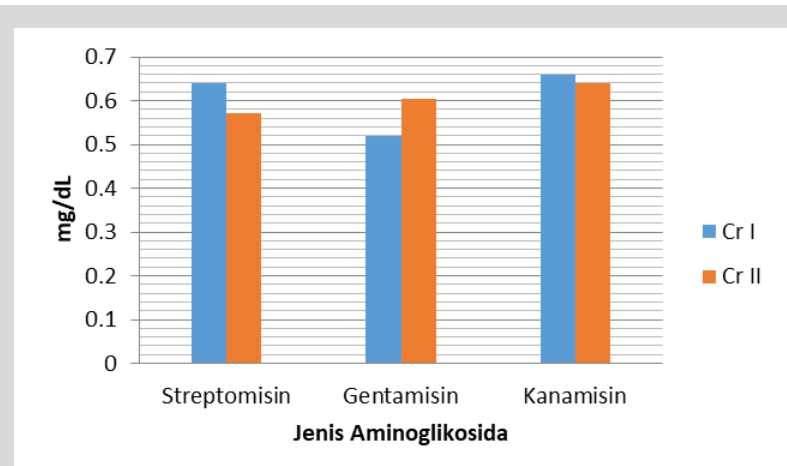

Gambar 1. Perbandingan rata-rata kadar kreatinin sebelum $(\mathrm{Cr} \mathrm{I})$ dan sesudah ( $\mathrm{Cr}$ II) penggunaan obat streptomisin, gentamisin, dan kanamisin.

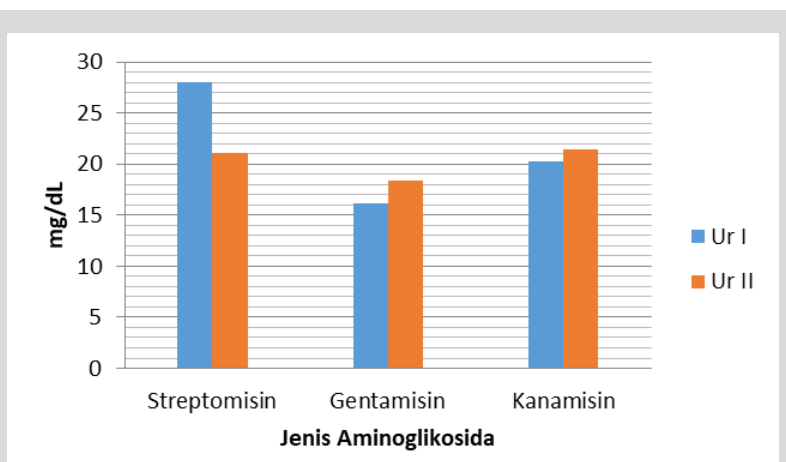

Gambar 2. Perbandingan rata-rata kadar ureum sebelum (Ur I) dan sesudah (Ur II) penggunaan obat streptomisin, gentamisin, dan kanamisin

Pada kelompok streptomisin hanya kelompok D yang menunjukkan peningkatan kadar kreatinin, sedangkan kelompok A, B dan C menunjukkan penurunan kadar kreatinin pada pemeriksaan kedua. Sedangkan pada pengukuran ureum untuk streptomisin tampak penurunan kadar ureum pada pemeriksaan kedua untuk kelompok A, B dan D sedangkan kelompok C tampak konstan. Sedangkan untuk kelompok gentamisin yang hanya terdiri dari kelompok A dan B, tampak pada pengukuran kreatinin kedua kelompok subjek menunjukkan peningkatan kreatinin pada pemeriksaan kedua, tetapi pada pengukuran ureum kelompok B menunjukkan penurunan kadar ureum pada pemeriksaan kedua walaupun penurunannya sangat kecil. Untuk kelompok kanamisin, kelompok A, C, dan D menunjukkan penurunan kadar kreatinin dan hanya kelompok B yang menunjukkan peningkatan kadar kreatinin pada pemeriksaan kedua. Pada kelompok streptomisin hanya kelompok D yang menunjukkan peningkatan kadar kreatinin, sedangkan kelompok A, B dan C menunjukkan penurunan kadar kreatinin pada pemeriksaan kedua. Kelompok terapi streptomisin tidak menunjukkan peningkatan kreatinin dan 
ureum yang tinggi, kecuali pada kelompok D yang diterapi dengan streptomisin selama lebih dari 31 hari. Hal tersebut bisa disebabkan oleh sifat nefrotoksik aminoglikosida yang meningkat seiring dengan bertambah lama waktu penggunaannya (4).

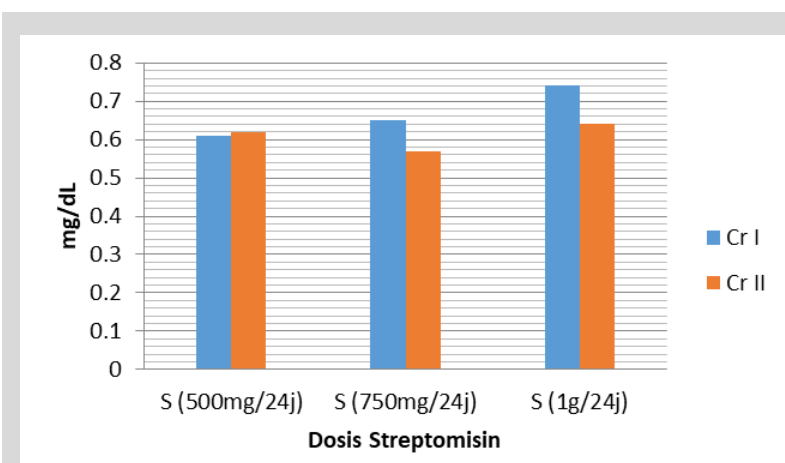

Gambar 3. Perbandingan rata-rata kreatinin serum pasien untuk penggunaan streptomisin antara kelompok dosis $500 \mathrm{mg} / 24 \mathrm{jam}$, $750 \mathrm{mg} / 24$ jam, dan $1 \mathrm{~g} / 24$ jam.

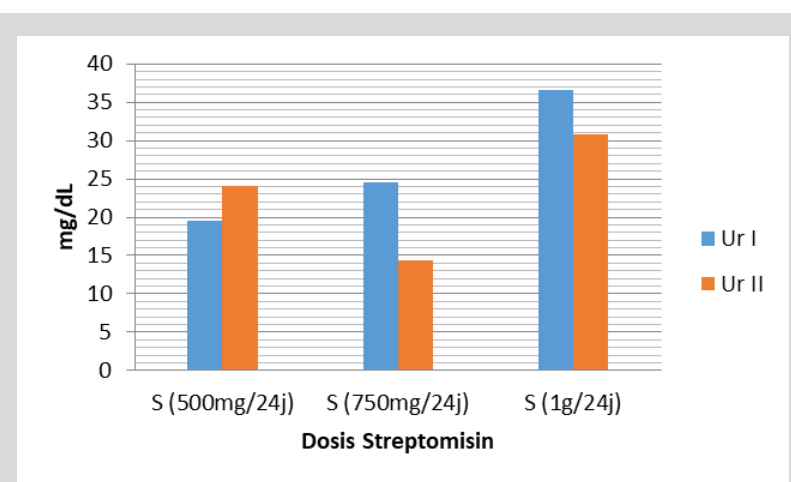

Gambar 4. Perbandingan rata-rata ureum serum pasien untuk penggunaan streptomisin antara kelompok dosis $500 \mathrm{mg} / 24$ jam, $750 \mathrm{mg} / 24$ jam, dan $1 \mathrm{~g} / 24$ jam.

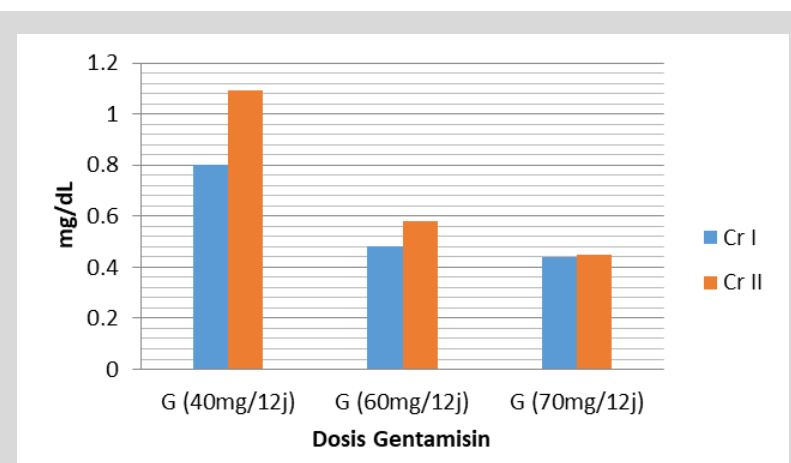

Gambar 5. Perbandingan rata-rata kreatinin serum pasien untuk penggunaan gentamisin antara kelompok dosis $40 \mathrm{mg} / 12$ jam, $60 \mathrm{mg} / 12 \mathrm{jam}$, dan $70 \mathrm{mg} / 12 \mathrm{jam}$.

Sedangkan gentamisin juga menunjukkan peningkatan kadar kreatinin pada perbandingan lama penggunaan terapi obat. Hal ini juga tampaknya disebabkan oleh penggunaan dosis terbagi pada kelompok gentamisin (masing-masing $40 \mathrm{mg} / 12$ jam, $60 \mathrm{mg} / 12 \mathrm{jam}$ dan $70 \mathrm{mg} / \mathrm{dl})(4,6)$. Sedangkan untuk kanamisin tampak peningkatan kadar kreatinin pada kelompok dosis $750 \mathrm{mg} / 24$ jam dan kelompok B (terapi obat selama 11-20 hari). Hal ini tampaknya diakibatkan karena sebagian subjek dari kelompok ini merupakan penderita diabetes melitus tipe 2. Walaupun terjadi peningkatan kreatinin serum pada sebagian kelompok, perubahan kreatinin serum tersebut tidak signifikan ( $p=0.246>0,05)$. Hal ini menunjukkan bahwa walaupun menggunakan dosis terbagi dan digunakan dalam waktu cukup panjang ( $>5$ hari) tidak tampak peningkatan yang signifikan dan juga tidak tampak kadar kreatinin melewati ambang batas kadar normal $(<1,3 \mathrm{mg} / \mathrm{dL}$ untuk pria, $1,1 \mathrm{mg} / \mathrm{dL}$ untuk wanita) pada kreatinin serum para subjek yang mengindikasikan efek nefrotoksik dari obat golongan aminoglikosida.

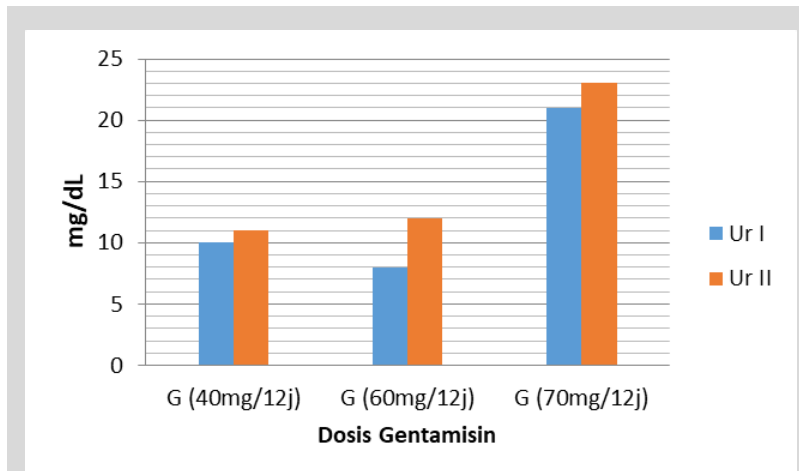

Gambar 6. Perbandingan rata-rata ureum serum pasien untuk penggunaan gentamisin antara kelompok dosis $40 \mathrm{mg} / 12$ jam, $60 \mathrm{mg} / 12 \mathrm{jam}$, dan $70 \mathrm{mg} / 12 \mathrm{jam}$.

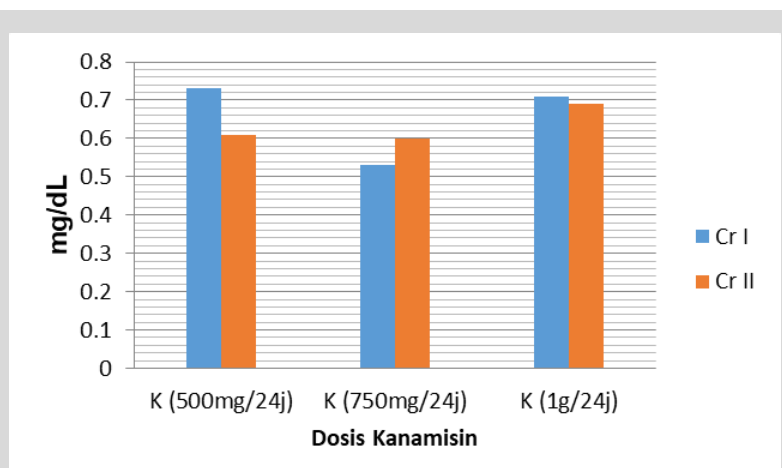

Gambar 7. Perbandingan rata-rata kreatinin serum pasien untuk penggunaan kanamisin antara dosis $500 \mathrm{mg} / 24 \mathrm{jam}, 750 \mathrm{mg} / 24$ jam, dan $1 \mathrm{~g} / 24$ jam..

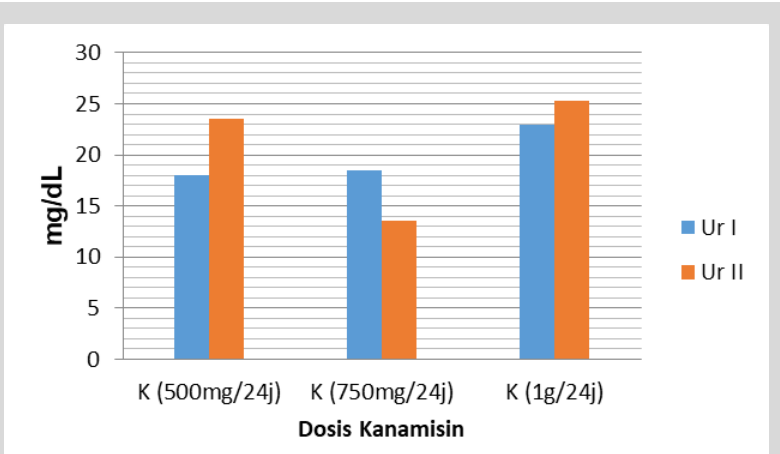

Gambar 8. Perbandingan rata-rata ureum serum pasien untuk penggunaan kanamisin antara dosis $500 \mathrm{mg} / 24$ jam, $750 \mathrm{mg} / 24$ jam, dan $1 \mathrm{~g} / 24$ jam.

Kelompok streptomisin menunjukkan pengaruh yang lebih ringan pada kadar kreatinin jika dibandingkan dengan kelompok gentamisin dan kanamisin. Hal ini disebabkan oleh sifat nefrotoksik streptomisin yang lebih ringan dibandingkan dengan kedua obat tersebut. Efek tersebut tampaknya dikarenakan toksisitas aminoglikosida diakibatkan oleh akumulasi dan retensi senyawa tersebut di sel-sel epitel tubular proksimal ginjal dan streptomisin adalah aminoglikosida yang tidak terkonsentrasi di korteks ginjal sehingga memiliki efek nefrotoksik terendah. Di antara ketiga aminoglikosida yang tersebut gentamisin merupakan aminoglikosida dengan efek nefrotoksik yang lebih besar dibandingkan kanamisin dan streptomisin karena gentamisin memiliki tingkat ekskresi yang lebih rendah dan tingkat reabsorbsi ginjal yang lebih tinggi $(5,7,9)$. 


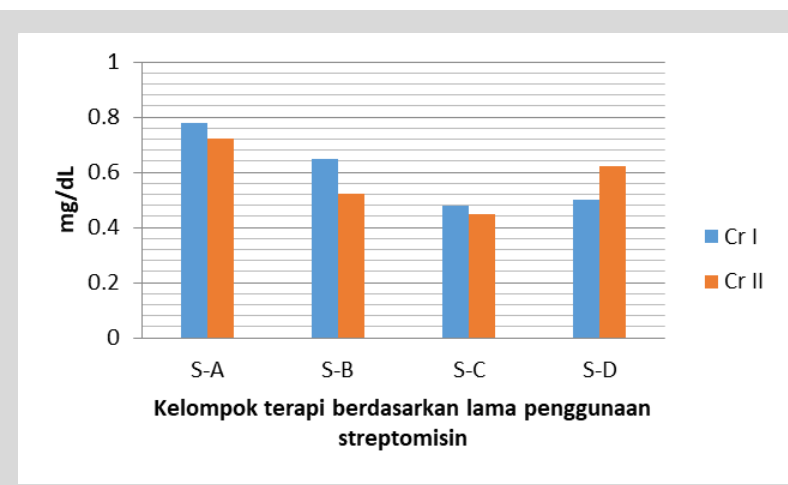

Gambar 9. Perbandingan rata-rata kreatinin serum pasien untuk penggunaan streptomisin antara kategori A (3-10 hari), B (11-20 hari), C (21-30 hari), D (>31 hari).

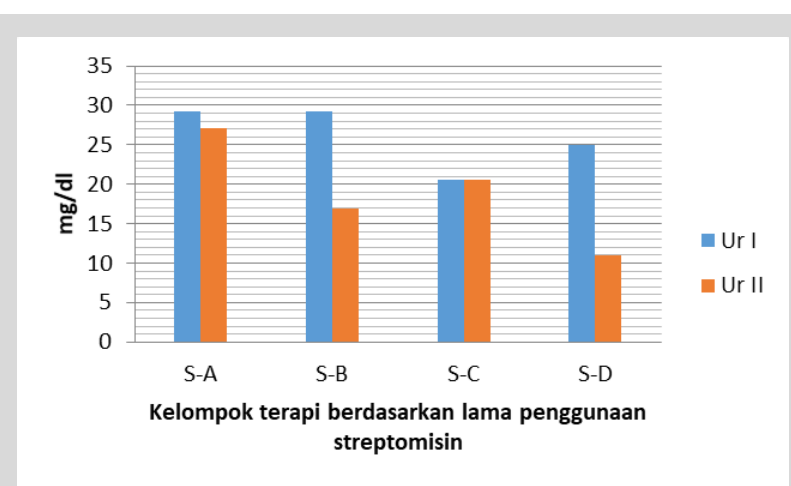

Gambar 10. Perbandingan rata-rata ureum serum pasien untuk penggunaan streptomisin antara kategori A (3-10 hari), B (11-20 hari), C (21-30), D (>31 hari)
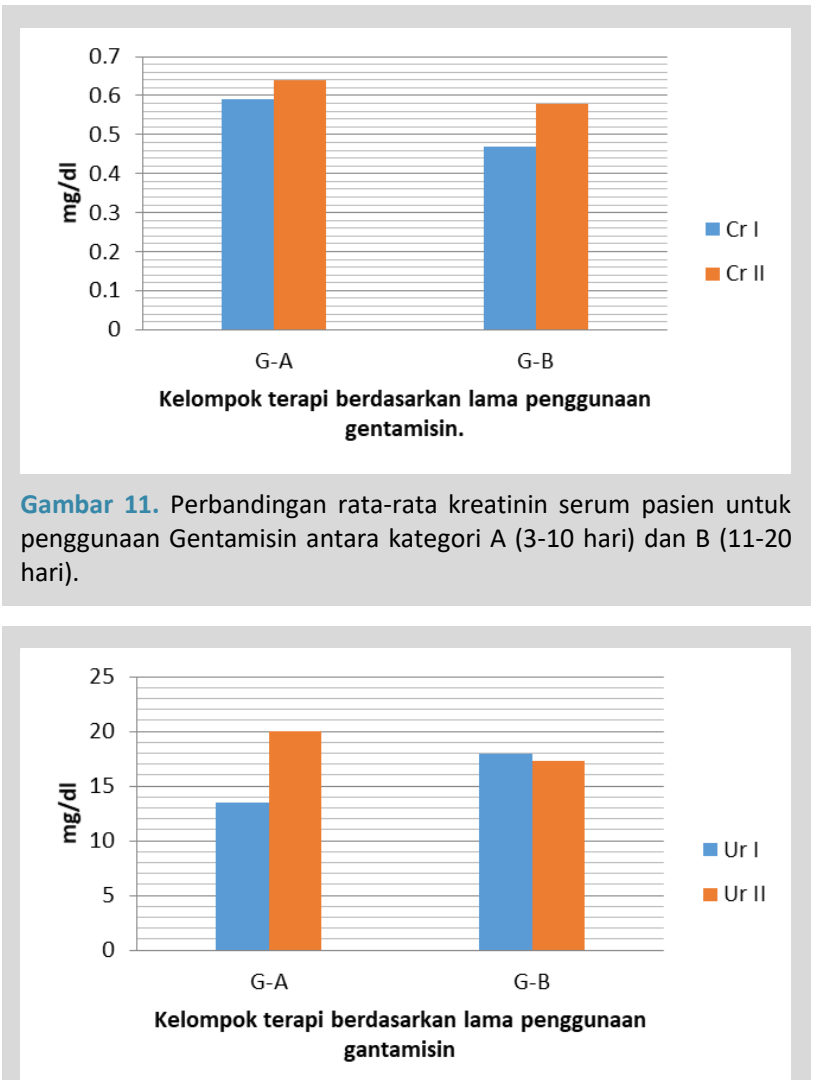

Gambar 12. Perbandingan rata-rata ureum serum pasien untuk penggunaan Gentamisin antara kategori A (3-10 hari) dan B (11-20 hari).

Kecenderungan terjadi akumulasi dari obat-obatan jenis aminoglikosida di tubulus proksimal ginjal disebabkan oleh sifat kationik dari senyawa golongan ini. Sifat kationik dari aminoglikosida disebabkan oleh keberadaan gugus amino dalam senyawa ini. Penyebab streptomisin tidak terakumulasi di korteks ginjal sehingga memiliki efek nefrotoksik yang rendah adalah karena obat ini memiliki jumlah gugus amino kationik yang lebih sedikit dibandingkan gentamisin dan kanamisin. Streptomisin memiliki tiga gugus amino kationik, sedangkan kanamisin memiliki empat gugus amino kationik dan gentamisin memiliki lima gugus amino kationik sel. Gentamisin yang memiliki sifat kationik paling kuat dengan mudah mengikat komponen fosfoinositid yang bermuatan negatif di membran pembatas tubulus proksimal ginjal $(4,8,10)$.

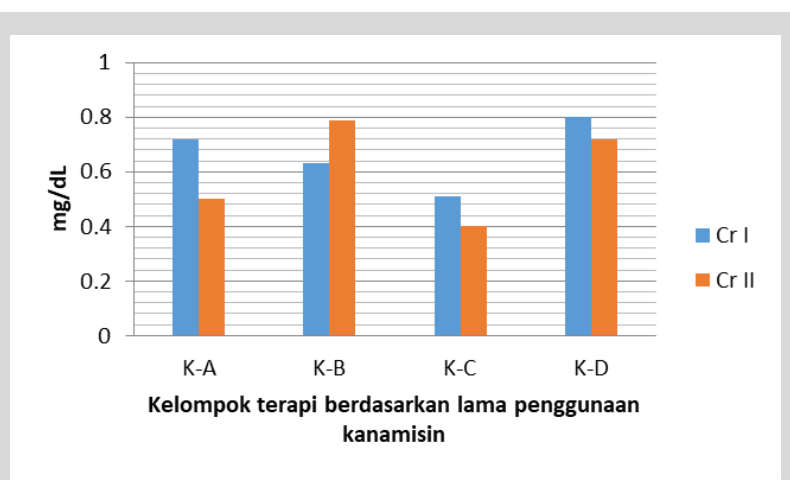

Gambar 13. Perbandingan rata-rata kreatinin serum pasien untuk penggunaan kanamisin antara kategori A (3-10 hari), B (11-20 hari), C (21-30), D (>31 hari).

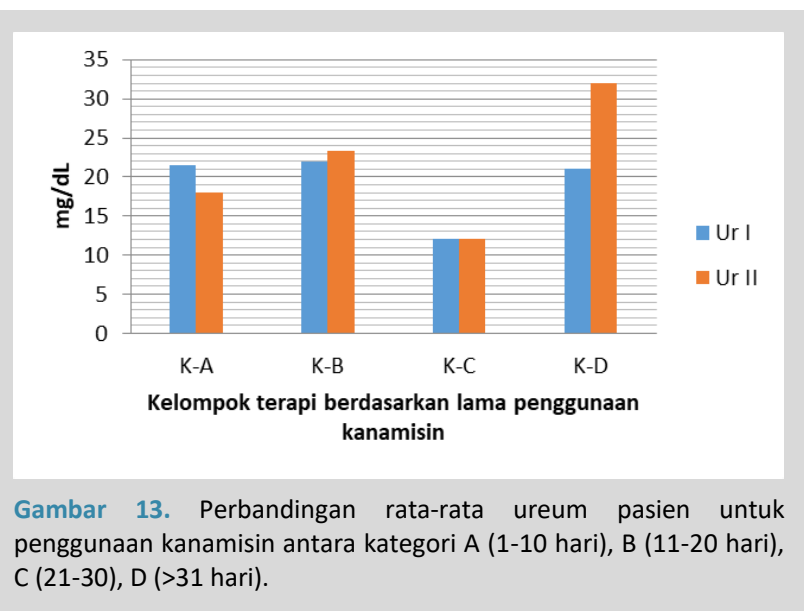

\section{KESIMPULAN}

Dalam penelitian ini tidak ditemukan perubahan yang signifikan antara kadar kreatinin sebelum dan sesudah penggunaan obat-obatan aminoglikosida, yaitu streptomisin, gentamisin dan kanamisin. Pada perbandingan berdasarkan dosis dan lama penggunaan terapi aminoglikosida juga tampak perbedaan yang tidak signifikan tetapi pada kelompok gentamisin terjadi peningkatan pada semua kelompok dosis dan lama penggunaan terapi yang tampaknya diakibatkan oleh penggunaan dosis terbagi pada kelompok obat ini. Pada penelitian ini tidak ditemukan kadar kreatinin dan ureum yang melebihi batas normal dan terjadi penurunan kadar kreatinin dan ureum pada beberapa subjek.

\section{DAFTAR PUSTAKA}

1. Katzung, Bertram G. Basic \& Clinical Pharmacology $14^{\text {th }}$ Edition. McGraw Hill Education. New York. 2018.

2. Wargo, Kurt A dan Edwards, Jonathan D. Aminoglycosides-Induced Nephrotoxicity. Journal of Pharmacy Practice. 2014, Vol 27:573-577.

3. Awdishu, L dan Mehta, RL. The 6R's of Drug Induced Nephrotoxicity. Biomed Central Nephrology. 2017,Vol 18:124 
4. Lopez-Novoa, JM., Quiros, Y., Vicente, L., Morales, AI., Lopez-Hernandez, FJ. 2011. New Insights into the Mechanism of Aminoglycoside Nephrotoxicity: AN Integrative Point of View. Kidney International. 2014, Vol 79: 33-45.

5. Brunton, L., Chabner, B., dan Knollman, B. Goodman \& Gilman's The Pharmacological Basis of Therapeutics $12^{\text {th }}$ Edition. McGraw-Hil Companies Inc. 2011.

6. Chen, Luke F dan Kaye, Donald. Current Use for Old Antibacterial Agents. Polymyxins, Rifamycins, and Aminoglycosides. Infect Dis Clin N AM. 2009, Vol 23: 1053-1075.
7. Finch, RG., Greenwood, D., Norrby, SR., dan Whitley, RJ. Antibiotic and Chemotherapy: Anti-Infective Agents and Their Use in Therapy $9^{\text {th }}$ Edition. Saunders-Elsevier Ltd. 2010.

8. Dipiro, JT., Talbert, RL., Yee, CC., Matzke, GR., Wells, BG., dan Posey, ML. Pharmacotherapy: A Pathophsiologic Approach $8^{\text {th }}$ Edition. McGraw-Hill Companies,Inc. 2011.

9. McQueen, Charlene A. Comprehensive Toxicology $2^{\text {nd }}$ Edition. Elsevier Ltd 2010.

10. Balakumar, P., Rohilla, A., Thangathirupthi, A. Gentamisin-induced Nephrotoxicity: Do we have a promising therapeutic approach to blunt it Pharmacologica Research. 2010, Vol 62:179-186. 